\title{
Different methods of real-time PCR for detection of pseudorabies virus
}

\author{
Carolina Kymie Vasques Nonaka ${ }^{1}$ Antônio Augusto Fonseca Junior ${ }^{2}$ Estefânia Oliveira Guedes ${ }^{1}$ \\ Régia Maria D'Ambros ${ }^{3}$ Graciela Kunrath Lima ${ }^{1}$ Marcelo Fernandes Camargos ${ }^{1}$ Marcos Bryan Heinemann ${ }^{4}$
}

${ }^{1}$ Escola de Veterinária, Departamento de Medicina Veterinária Preventiva, Universidade Federal de Minas Gerais (UFMG), Belo Horizonte, MG, Brasil. ${ }^{2}$ Laboratório Nacional Agropecuário Lanagro/MG, Ministério da Agricultura, Pecuária e Abastecimento, Pedro Leopoldo, MG, Brasil. ${ }^{3}$ Centro de Diagnóstico em Sanidade Animal (CEDISA), Concórdia, SC, Brasil.

${ }^{4}$ Departamento de Medicina Veterinária Preventiva, Faculdade de Medicina Veterinária e Zootecnia, Av. Prof. Dr. Orlando Marques de Paiva, 87, 5508-270, São Paulo, SP, Brasil. E-mail: marcosbryan@usp.br. Corresponding author.

ABSTRACT: Pseudorabies (PR) is a highly contagious viral disease of great animal health and economic importance in swine industry. The aim of this study was to evaluate different genomic regions, real-time PCR chemistries and equipment for the molecular diagnosis of PR. Eight primer pairs targeting four genes $(g B, g C, g E, g D)$, three different $q P C R$ chemistries (SybrGreen, hydrolysis probes and plexor) and two equipment (ABI7500, Rotorgene 3000) were evaluated. Oligonucleotides targeting gB using hydrolysis probes showed the best performance after evaluating efficiency (99\%), the detection limit $\left(10^{-1.5}\right.$ TCID50 $\left.\mathrm{mL}^{-1}\right)$ and diagnostic sensitivity and; therefore, those primers were selected for performance verification factors such as repeatability, reproducibility and robustness (1.39\% variance between days, $24 \%$ variance between analysts and $4.07 \%$ variance in analysis error). The qPCR standardized and validated in this research proved to be reliable for the diagnosis of PR and may be used in diagnostic laboratories that follow ISO 17025 and ISO 16140.

Key words: real time PCR, pseudorabies, diagnose.

Diferentes métodos de PCR em tempo real para detecção do vírus da pseudorraiva

RESUMO: Pseudorraiva (PR) é uma doença viral altamente contagiosa de grande importância sanitária e econômica na indústria suína. O objetivo deste estudo foi avaliar diferentes regiões genômicas, químicas de PCR em tempo real e equipamentos para o diagnóstico molecular de PR. Foram avaliados quatro genes (GB, GC, GE, gD), três diferentes produtos químicos (SybrGreen, sondas de hidrólise e plexor) e dois equipamentos (ABI7500, Rotorgene 3000). Oligonucleotídeos com alvo para gB baseados na química de sondas de hidrólise apresentaram o melhor desempenho nos testes de eficiência (99\%), de limite de detecção (10-1.5 TCID50 $\mathrm{mL}^{-1}$ ) e sensibilidade diagnóstica. Portanto, estes foram selecionados para fatores de verificação de desempenho, tais como a repetibilidade, reprodutibilidade e robustez (1,39\% de variância entre dias, $24 \%$ variância entre analistas e 4,07\% de variância por erro de análise). A qPCR, padronizada e validada neste trabalho, mostrou-se confiável para o diagnóstico de PR e pode ser utilizada em laboratórios de diagnóstico que se seguem normas internacionais como ISO 17025 e ISO 16140. Palavras-chave: PCR em tempo real, pseudorraiva, diagnóstico.

\section{INTRODUCTION}

Pseudorabies (PR), also known as Aujeszky's disease, is a highly contagious viral disease of great sanitary and economic importance in pigs (OIE, 2015). Pigs are considered the main reservoir of the virus and its most important disseminator. The disease is caused by Suid herpesvirus 1 (SuHV-1, family Herpesviridae) (DAVISON et al., 2009).

Cases of SuHV-1 infection can be found in parts of Europe, Southeast Asia, Central America and South America (OIE, 2015). Besides the infection of domestics pigs, common problem is the high number of feral pigs and wild boar infected by SuHV-1. In the United States, different publications presented a percentage of positive samples varying from $0 \%$ to $60.91 \%$ in the states were the samples were collected (MÜLLER et al., 2011). Two researches were done in Brazil. The first one used 358 samples from 1998-2001 collected from different farms and demonstrated prevalence varying from $0 \%$ to $55.9 \%$ positive samples in ELISA (CUNHA et al., 2006). The second research was done with 186 samples collected from feral pigs throughout the Brazilian wetland plain, obtaining $31.8 \%$ positive in serum neutralization (PAES et al., 2013). Due to the health risk, the fact of being a notifiable disease that imposes severe sanitary barriers, PR is still constantly studied to evaluate methods of rapid and accurate diagnosis (OIE, 2015). 
PR diagnosis is performed by detection of the agent as virus isolation and identification or polymerase chain reaction as well as by detecting a serological response against SuHV-1. Viral isolation has the disadvantage of relying on the presence of viable viruses and the possibility of contamination of cell cultures (JULIAN \& SCHWAB, 2012). The tests based on the antibody detection have the disadvantage of depending on the seroconversion of the animal. Use of these tests during the acute phase of the disease can lead to false-negative results, because it takes at least 10 days after infection, on average, for the detection of antibodies. Another disadvantage is that younger animals may die before seroconversion, hindering serological diagnosis (KINKER et al., 1997).

A growing number of real time PCR (qPCR) chemistries are available to diagnostic laboratories. There are differences in performance of these methods concerning costs, detection limits, specificity and practicability (BUH GASPARIC et al., 2008). It is important to evaluate each chemistry, because its optimization and costs may have a impact in laboratory analysis. Detection limit, for example, occasionally changes according to qPCR chemistry used, which affects diagnostics sensitivity and indicates these molecular methodologies are not easily interchangeable (GHALMI et al., 2008).

International guides such as the Manual of Diagnostic Tests and Vaccines for Terrestrial (OIE, 2015) and laboratory quality systems (ISO $17025,2010)$ highlight the importance of checking the performance of analytical methods and documentation of the validation research to obtain reliable and appropriate results for the intended use. The aim of this study was to develop and verify the performance of molecular methods for detection of SuHV-1 targeting different genes, real time PCR chemistries and equipment.

\section{MATERIALS AND METHODS}

Samples were allocated into three groups: 1 - sixteen isolated viruses (including standard sample Shope and vaccine strain Bartha), 2 - spiked samples for use in detection limit and performance verification and 3-25 positive and 85 negative clinical specimens (swine brain) with results in other techniques diagnosis (virus isolation for the tissue and virus neutralization from serum collected from each animal). Each group is described below.

Virus isolates used in this research were the standard strain Shope, vaccine strain Bartha and fourteen Brazilian SuHV-1 isolates (four genotype I and ten genotype II) previously characterized by FONSECA JR. et al. (2010a) and FONSECA JR et al. (2012). Viruses were grown in PK15 cells and DNA extracted as described by FONSECA JR et al. (2010b) (Group 1). All cells were previously tested for contamination (PPV, PCV-2, Mycoplasma, BVDV) as described by PINHEIRO de OLIVEIRA et al. (2013).

The spiked samples were brains of pigs from farms located in the free zone for PR and without history of PR. Each tissue was spiked with the standard strain Shope multiplied in PK-15 cell $\left(10^{4.5} \mathrm{TCID}_{50} \mathrm{~mL}^{-1}\right)$. Six of these samples were used to evaluate the detection limit. Virus suspension was diluted in base ten in TE $(10 \mathrm{mM}$ Tris $\mathrm{HCl} 1 \mathrm{mM}$ EDTA, $\mathrm{pH} 8$ ) from $10^{-1}$ to $10^{-6}$. Twenty five mg of porcine brain tissue were spiked with approximately $600 \mu \mathrm{L}$ of the virus dilutions. DNA was extracted from the porcine brain tissues spiked and from the virus dilution in parallel so that the detection limit could be compared in the presence and absence of pig tissue (Group 2).

Clinical samples used were brains of domestic swine positive for PR and were described in a previous experiment (FONSECA JR et al., 2010b). DNA was extracted using phenol/chloroform method according to SAMBROOK et al. (2001). The evaluation of the extracted DNA and the presence of inhibitors were performed based on the detection of GAPDH gene using primers GAPDH.230.F (5'GGGCGTGAACCATGAGAAGT3') and GAPDH.230.R (5'AAGCAGGGATGATGTTCTGG3') in a $20 \mu \mathrm{L}$ reaction in the following conditions: $0,4 \mu \mathrm{M}$ of each primer, $10 \mu \mathrm{L}$ of SybrGreen PCR Master Mix (Applied Biosystems, USA) and thermocyling conditions according to the manufacturer.

SuHV-1 conserved sequences were selected as target for PCRs after alignment using the software BioEdit Sequence Alignment Editor (HALL, 1999). Oligonucleotides (primers and probes) for SYBR Green and hydrolysis probe chemistries were designed using the software Primer3Plus. Primers for Plexor technology were designed using the software Plexor Primer Design (Promega, USA) (Table 1). Oligonucleotide specificity was tested in silico using PrimerBlast program (NCBI).

All qPCR tests were performed using trial and error adjustments in oligonucleotide concentration and annealing temperature. Each technique was assessed according to reaction efficiency and detection limits for the choice 
Table 1 - Primers used in this research for molecular detection of SuHV-1 targeting different genomic regions and using different qPCR chemistries.

\begin{tabular}{|c|c|c|c|c|}
\hline Primers ${ }^{1}$ & Sequence $\left(5^{\prime}-3^{\prime}\right)$ & Position $^{2}$ & Amplicom Size (bp) & PCR Efficiency \\
\hline gB-Sybr-R & GGTTCAGGGTACCCCGC & $16697-16713$ & \multirow[b]{2}{*}{195} & \multirow[b]{2}{*}{78} \\
\hline gB-Sybr-F & ACGGCACGGGCGTGATC & $16891-16875$ & & \\
\hline gC-Sybr-R & GACACCTCGCCCGAGAC & $53614-53598$ & \multirow[b]{2}{*}{104} & \multirow[b]{2}{*}{0} \\
\hline gC-Sybr-F & CTCTTCAGCTCCGCCAAC & $53508-53525$ & & \\
\hline gD-Sybr-R & GCCACCGCCTCGTTCAGC & $119903-119886$ & \multirow[b]{2}{*}{123} & \multirow[b]{2}{*}{90} \\
\hline gD-Sybr-F & GGTCCCCTCGCCCTTCGTC & 119781-119799 & & \\
\hline gE-Sybr-R & GGAGAGACGATGGGGTGAGT & $45470-45451$ & \multirow[b]{2}{*}{116} & \multirow[b]{2}{*}{75} \\
\hline gE-Sybr-F & GACGGATGTGATGTTGCTGA & $45355-45374$ & & \\
\hline gB-Taq-F & CTCCTGCCGCACCTGAAG & 19665-19648 & \multirow{3}{*}{92} & \multirow{3}{*}{99} \\
\hline gB-Taq-R & GTCTGGAAGCGGTAGAAGCC & 19574-19593 & & \\
\hline gB-Taq-P & 56-FAM/CGGAACTCGCTGACGCACCA & & & \\
\hline gE-Taq-R & GATGCAGGGCTCGTACAC & $122148-122131$ & \multirow{3}{*}{136} & \multirow{3}{*}{96} \\
\hline gE-Taq-F & GGACACGTTCGACCTGATG & $122013-122031$ & & \\
\hline gE-Taq-P & 5CY5/AGCGTGGCGGTGAAGTTCTCG & & & \\
\hline gD-Plexor-R & GACTACATGTTCCCCACGGAGGA & $120064-120086$ & \multirow[b]{2}{*}{76} & \multirow[b]{2}{*}{88} \\
\hline gD-Plexor-F & FAM-5-iso-dC-GGTACTGGCCCTCGTTGAACC & 120139-120119 & & \\
\hline gE-Plexor-R & GCCACGCTGGACTGGTACTAC & $122077-122097$ & \multirow{2}{*}{126} & \multirow{2}{*}{86} \\
\hline gE-Plexor-F & TexRd-iso-dC- GAAGCTGCACGCCGGGTCCA & $122202-122192$ & & \\
\hline
\end{tabular}

${ }^{1}$ The names of each oligonucleotide are formed by the name of the protein encoded by the gene followed by the qPCR system. Sybr: SybrGreen, Taq: hydrolysis probe, Plexor: Plexor (Promega, USA).

${ }^{2}$ Position in complete genome sequence of strain Becker (GenBank acess number: JF797219.1).

of the best oligonucleotides for each chemistry. All tests were performed with appropriate positive and negative controls, DNA extraction controls typically used for molecular methods. The following kits were used in each reaction: TaqMan ${ }^{\circledR}$ Fast Universal PCR Master Mix (Applied Biosystems, USA); SybrGreen PCR Master Mix (Applied Biosystems, USA) and $\mathrm{GoTaq}^{\circledR}$ qPCR Master Mix Plexor System (Promega, USA).

The efficiency of the qPCR reactions were tested using dilutions of DNA samples spiked with the standard strain Shope. Each dilution was tested in triplicate with different DNA concentrations in order to determine the optimal amount of nucleic acid to be added to reaction mixes (50ng $\mu \mathrm{L}^{-1}$ or $100 \mathrm{ng} \mu \mathrm{L}^{-1}$ ). DNA concentrations were estimated by spectrophotometry (NanoVue ${ }^{\circledR}, \mathrm{GE}$ Healthcare, USA). The efficiency of each PCR technique was assessed using standard curves and analyzing the values of $\mathrm{R}^{2}$, slope and limit of detection (LD).

PCRs with the highest efficiencies in each qPCR chemistries were selected to the following tests: selectivity tests, diagnostic specificity and diagnostic sensitivity. Only the qPCR with the best results in these tests was selected for repeatability and reproducibility.

Following the OIE criteria (OIE, 2015), selectivity tests were performed (exclusion and inclusion). The inclusion tests were conducted using fourteen SuHV-1 isolates from two different genetic groups and vaccine strain Bartha (FONSECA JR et al., 2012). Exclusion tests were performed with classical swine fever virus, African swine fever virus, bovine herpesvirus 1 , porcine parvovirus, porcine circovirus 2 and Streptococcus suis.

Diagnostic specificity was tested using seventy samples (swine brain) collected from three 
farms with no history of PR. Samples were collected from adult animals in a slaughterhouse. Animals were previously tested by virus neutralization test and the tissues submitted to a nested PCR (FONSECA JR et al., 2010b). Diagnostic sensitivity was evaluated using twenty-five samples (swine brain collected from animals form farms in the state of Santa Catarina in 2003; DNA extracted three years before this study) positive in viral isolation and in a nested PCR (FONSECA JR et al., 2010b). Viruses presented in clinical sample were characterized as genotype II in the cited publication.

Performance verification was done only with the methodology with better efficiency and LD as proposed by FONSECA JR et al. (2013). Testing repeatability occurred on three consecutive days, using seven different samples in triplicate (a sample in LD concentration, three samples a $\log$ above LD and three samples $1 / 2 \log$ above LD in the respective concentrations from, $10^{-1.5}$ TCID50 $\mathrm{mL}^{-1}, 10^{-1.0}$ TCID50 $\mathrm{mL}^{-1}$ and $10^{-0.5}$ TCID50 $\mathrm{mL}^{-1}$ ). The same procedures were repeated for a second person. Statistical analysis for reproducibility and repeatability was done by calculation of variances and as described by ISO 16140 (2003).

The robustness was evaluated with the same samples. It was considered relevant to the methodology: pipetting error, reagent change and thermocycler. Thus, the variables tested were: the variation of $+1 \mu \mathrm{L}$ and $-1 \mu \mathrm{L}$ in the final volume of reaction; comparison of the equipment Rotor Gene 3000 (Qiagen, USA) with results obtained in 7500 machine (Applied Biosystem, USA) and we used UNG-dUTP qPCR Master Mix Kit (6mM $\mathrm{MgCl}_{2}$ ) (Ampliqon, Germany) for comparison with the TaqMan ${ }^{\circledR}$ Universal Fast PCR Master Mix.

For interlaboratory reproducibility, thirty negative and thirty positive spiked samples were used. Negative samples were composed of approximately $25 \mathrm{mg}$ of tissue (swine brain) and $600 \mu \mathrm{L}$ of TE. Samples were divided in two parts, one was tested in the laboratory and another part sent to the Animal Virology Laboratory in Veterinary school at the Universidade Federal de Minas Gerais. Thermocycler used in the interlaboratory test was the Real-time 7500 (Applied Biosystems, USA). DNA extraction was performed with extraction kit AccuPrep ${ }^{\circledR}$ Genomic DNA Extraction (Bioneer Corporation, USA). The PCR reaction used the TaqMan ${ }^{\circledR}$ Fast Universal PCR Master Mix (Applied Biosystems, USA).

\section{RESULTS}

Oligonucleotides were analyzed for dimer formation and $\mathrm{dG}$ due to self anneling or loop formation. The gB-Sybr had 15 primer dimers and a maximum dG of $16.30 \mathrm{kcal} \mathrm{mol}^{-1}$. gE-Sybr had no primer dimer. Reaction efficiencies varied from $0 \%$ to $99 \%$ (Table 1). All qPCRs amplified DNA from strain Shope, but reactions targeting $\mathrm{gE}$ did not amplify DNA from vaccine strain Bartha. Only reactions with best efficiency for each qPCR chemistrie were included in the following tests. Oligonucleotides targeted to gB (hydrolysis probe) and $\mathrm{gD}$ (system SYBRGreen and Plexor) were selected due to higher efficiency.

In relation to the amount of DNA, concentrations of $50 \mathrm{ng} \mu \mathrm{L}^{-1}$ and $100 \mathrm{ng} \mu \mathrm{L}^{-1}$ were tested. As there was no significant difference between the amounts of amplification of DNA tested, it was decided that the lower amount of DNA would be used in all tests in order to obtain a test with less interfering substances.

The final volume of all qPCRs was $20 \mu \mathrm{L}(18 \mu \mathrm{L}$ of mix and $2 \mu \mathrm{L}$ of DNA). Reagents concentrations for the qPCR with the best performances were: $0.375 \mathrm{pmol} \mu \mathrm{L}^{-1}$ of each primer, $10 \mu \mathrm{L}$ of $2 \mathrm{X}$ Master Mix and $0.8 \%$ DMSO $\left(\right.$ Amresco $\left.{ }^{\circledR}\right)$. Probe concentration was $0.2 \mathrm{pmol} \mathrm{uL}^{-1}$ in the hydrolysis probe technique.

The first tests were performed only with the dilutions of the standard strain Shope, followed by phenol/chloroform extraction. The following LD were found for the different detection systems: $10^{-0.5}$ TCID50 $\mathrm{mL}^{-1}$ for gD-SYBR, $10^{-1.5}$ TCID50 $\mathrm{mL}^{-1}$ for $\mathrm{gD}$-Plexor, $10^{-2.5}$ TCID50 $\mathrm{mL}^{-1}$ for gB-Taq. In the following test, a new standard curve was constructed with approximately $25 \mathrm{mg}$ of porcine brain tissue (per tube) spiked with virus suspension to determine the matrix interference in the SuHV1 DNA amplification. For all systems tested, a new LOD was reported: $10^{0.5} \mathrm{TCID} 50 \mathrm{~mL}^{-1}$ (gD-SYBR), from $10^{-0.5}$ TCID50 $\mathrm{mL}^{-1}$ (gD-plexor), from $10^{-1.5}$ TCID50 $\mathrm{mL}^{-1}$ (gB-Taq).

Analytical specificity was tested to verify the interference of other infectious agents. The three best qPCR for each chemistry were tested and proven to be high specific $(100 \%)$. The qPCR did not amplify DNA from any organisms save from SuHV-1 isolates.

Twenty-five positive samples were tested for diagnostic sensitivity. The qPCR-gBTaq presented the highest diagnostic sensitivity, amplificating all positive samples (100\% diagnostic sensitivity). qPCR-gD-Sybr and PCR-gD-plexor had $72 \%$ and $96 \%$ diagnostic sensitivity, respectively. The three qPCRs did not present any amplification in the negative samples tested. 
Table 2 - Statistics generated from the Cts of qPCR-gB-Taq using samples at a concentration of $200 \mathrm{ng} / \mathrm{uL}$.

\begin{tabular}{|c|c|c|c|c|c|c|c|}
\hline \multirow{3}{*}{ Sample } & \multirow{2}{*}{ Data } & \multicolumn{3}{|c|}{ 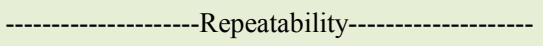 } & \multicolumn{3}{|c|}{ - } \\
\hline & & Day 1 & Day 2 & Day 3 & Day 1 & Day 2 & Day 3 \\
\hline & Mean & 29.502 & 28.240 & 29.132 & 28.803 & 26.987 & 29.632 \\
\hline \multirow[t]{3}{*}{1} & $\sigma$ & 0.134 & 0.160 & 0.057 & 0.097 & 0.100 & 0.135 \\
\hline & $\mathrm{CV} \%$ & 0.5 & 0.6 & 0.2 & 0.3 & 0.4 & 0.5 \\
\hline & Mean & 29.887 & 27.348 & 27.284 & 28.618 & 27.186 & 29.686 \\
\hline \multirow[t]{3}{*}{2} & $\sigma$ & 0.085 & 0.121 & 0.014 & 0.040 & 0.648 & 0.124 \\
\hline & $\mathrm{CV} \%$ & 0.3 & 0.4 & 0.1 & 0.1 & 2.4 & 0.4 \\
\hline & Mean & 28.711 & 28.279 & 27.329 & 28.823 & 26.389 & 30.612 \\
\hline \multirow[t]{3}{*}{3} & $\sigma$ & 0.589 & 0.241 & 0.296 & 0.493 & 0.082 & 0.197 \\
\hline & $\mathrm{CV} \%$ & 2.1 & 0.9 & 1.1 & 1.7 & 0.3 & 0.6 \\
\hline & Mean & 31.500 & 30.451 & 29.554 & 30.733 & 28.926 & 32.497 \\
\hline \multirow[t]{3}{*}{4} & $\sigma$ & 0.322 & 0.210 & 0.351 & 0.067 & 0.088 & 0.178 \\
\hline & $\mathrm{CV} \%$ & 1.0 & 0.7 & 1.2 & 0.2 & 0.3 & 0.5 \\
\hline & Mean & 31.561 & 30.264 & 29.820 & 30.635 & 30.123 & 31.528 \\
\hline \multirow[t]{3}{*}{5} & $\sigma$ & 0.078 & 0.114 & 0.166 & 0.190 & 0.882 & 0.154 \\
\hline & $\mathrm{CV} \%$ & 0.2 & 0.4 & 0.6 & 0.6 & 2.9 & 0.5 \\
\hline & Mean & 32.339 & 30.601 & 30.048 & 30.593 & 29.501 & 32.932 \\
\hline \multirow[t]{3}{*}{6} & $\sigma$ & 0.372 & 0.209 & 0.083 & 0.061 & 0.976 & 0.281 \\
\hline & $\mathrm{CV} \%$ & 1.2 & 0.7 & 0.3 & 0.2 & 3.3 & 0.9 \\
\hline & Mean & 33.057 & 31.244 & 31.039 & 32.800 & 31.151 & 35.560 \\
\hline \multirow[t]{2}{*}{7} & $\sigma$ & 0.241 & 0.177 & 0.172 & 0.505 & 0.586 & 0.123 \\
\hline & $\mathrm{CV} \%$ & 0.7 & 0.6 & 0.6 & 1.5 & 1.9 & 0.3 \\
\hline
\end{tabular}

We tested only qPCR-gB-Taq for performance verification due to its high diagnostic sensitivity. Data analysis by the coefficient of variance $(\mathrm{CV})$, using seven samples in triplicates within three days of repeatability and reproducibility yielded the following results (Table 2). The CV was $5 \%$ for qPCR using $50 \mathrm{ng} \mu \mathrm{L}^{-1}$ of DNA and $8 \%$ for qPCR using 100ng $\mu \mathrm{L}^{-1}$ of DNA. These results show a low dispersion of the data, demonstrating that the developed method was stable and homogenous for both DNA concentrations. Statistical analysis as described by ISO 16140 (2003) indicated $1.39 \%$ variance between days, $24 \%$ variance between analysts and $4.07 \%$ variance in analysis error. The sum of those errors is below $30 \%$, which indicated that the tests are adequate.

The next step was the robustness evaluation. Thus, variations considered significant for the method were: thermal cycler (CV 5.5\%), Master Mix (CV $1 \%$ ) and pipetting error. The change of equipment and Master Mix did not affect the performance of the method. Reducing the reaction volume by $1 \mu \mathrm{L}$ did not interfere with the results and adding $1 \mu \mathrm{L}$ to the reaction mix suggested that an increase in the final volume of the reaction could lead to increased analytical sensitivity. There was $100 \%$ concordance in diagnostic sensitivity (positive samples) and 100\% concordance in specificity (negative samples) in the interlaboratory tests.

\section{DISCUSSION}

Real-time PCR is an important tool in diagnosis. The viral detection by PCR in a latent or replicative state is a key tool in disease control (YOON et al., 2006). qPCR offer advantages like reduced risk of cross-contamination, shorter time required to perform the technique and excellent sensitivity and specificity.

There are other PCRs for detection of SuHV-1 described in the literature. A nested-PCR (FONSECA JR et al., 2010a) tested using the same samples to test analytical sensitivity had the same results for gD-plexor, was one log more sensible than gB-SYBR and one log less sensible than gB-Taq. Two hydrolysis probe $\mathrm{qPCR}$ for $\mathrm{gE}$ and $\mathrm{gB}$ described by MA et al. (2008) presented similar results, with $\mathrm{gE}$ less sensible than $\mathrm{gB}$, but no PCR was able to amplify samples stored for more than 10 years as done in this research These PCRs, as well as others (YOON et al., 
2005; YOON et al., 2006; PEREZ \& ARCE, 2009), were not subjected to all steps in a validation such as described here (repeatability and reproducibility, interlaboratorial tests).

Repeatability and reproducibility tests indicated that qPCR-gB-Taq performs well under requirements described by ISO 1640 (2003). Robustness tests indicated that the qPCR-gB-Taq is not subject to the interferences analyzed. The CV in the use of other equipment was 5.5\% and replacement of the master mix obtained a CV of $1 \%$, demonstrating that exchanging equipment and replacement of Master Mix did not affect the performance of the method. A significant CV must be greater than $15 \%$. The increased amount of mix suggested an increase in sensitivity, but further tests are needed to verify if this would be beneficial to the assay, since increasing the final volume of the reaction also increased the cost of the reaction and, perhaps, decreased specificity.

This study demonstrated the importance of performance verification and the use of clinical samples in development of qPCR for diagnoses. The qPCR standardized and validated in this research proved to be reliable for the diagnosis of PR and may be used in diagnostic laboratories that follow Quality Assurance described by International Standard Guidelines like ISO 17025 (2010) and ISO 16140 (2003).

\section{ACKNOWLEDGEMENTS}

The authors are thankful for the financial support from Fundação de Amparo à Pesquisa do Estado de Minas Gerais (Fapemig), Coordenação de Aperfeiçoamento de Pessoal de Nível Superior (Capes/Proex) and Conselho Nacional de Desenvolvimento Científico e Tecnológico (CNPq). M. B. H. is research fellows of Conselho Nacional de Desenvolvimento Científico e Tecnológico (CNPq).

\section{REFERENCES}

BUH GASPARIC, M. et al. Comparison of different real-time PCR chemistries and their suitability for detection and quantification of genetically modified organisms. BMC Biotechnology, v.8, p.26, 2008. Available from: $<$ https://bmcbiotechnol.biomedcentral.com/ articles/10.1186/1472-6750-8-26>. Accessed: Mar. O8, 2016. doi: $10.1186 / 1472-6750-8-26$.

CUNHA, E. M. S. et al. Antibodies against pseudorabies virus in feral swine in southeast Brazil. Arquivo Brasileiro de Medicina Veterinária e Zootecnia, v.58, n.4, p.462-466, 2006. Available from: $<$ http://www.scielo.br/scielo.php?script=sci_arttext\&p id=S0102-09352006000400002 >. Accessed: Mar. O8, 2016. doi: 10.1590/S0102-09352006000400002.

DAVISON, A. J. et al. The order Herpesvirales. Archives of Virology, v.154, n.1, p.171-177, 2009. Available from: <http://link. springer.com/article/10.1007\%2Fs00705-008-0278-4>. Accessed: Mar. O8, 2016. doi: 10.1007/s00705-008-0278-4.
FONSECA JR, A. A. et al. Diagnóstico e genotipagem do vírus da pseudorraiva por nested-PCR e análise de restrição enzimática. Ciência Rural, v.40, n.4, p.921-927, 2010a. Available from: <http:// www.scielo.br/pdf/cr/v40n4/a542cr2112.pdf>. Accessed: Mar. 08, 2016. doi: 10.1590/S0103-84782010005000066.

FONSECA JR, A. A. et al. Molecular epidemiology of Brazilian pseudorabies viral isolates. Veterinary Microbiology, v.141, n.3, p.238-245, 2010b. Available from: <http://www.sciencedirect. com/science/article/pii/S0378113509004350>. Accessed: Mar. 08, 2016. doi: 10.1016/j.vetmic.2009.09.018.

FONSECA Jr, A. A. et al. PCR em tempo real para detecção do vírus da doença de Aujeszky. Arquivos Brasileiros de Medicina Veterinária e Zootecnia, v.65, n.3, p.801-808, 2013. Available from: <http://www.scielo.br/pdf/abmvz/v65n3/28.pdf $>$. Accessed: Mar. 08, 2016. doi: 10.1590/S0102-09352013000300028.

FONSECA JR, A. A. et al. Pseudorabies virus can be classified into five genotypes using partial sequences of UL44. Brazilian Journal of Microbiology, v.43, n.4, p.1632-1640, 2012. Available from: <http://www.scielo.br/pdf/bjm/v43n4/48.pdf $>$. Accessed: Mar. 08, 2016. doi: 10.1590/S1517-83822012000400048.

GHALMI, F. et al. Detection of Neospora caninum in dog organs using real time PCR systems. Veterinary Parasitology, v.155, n.12, p.161-167, 2008. Available from: <http://www.sciencedirect. com/science/article/pii/S0304401708001945>. Accessed: Mar. 08, 2016. doi: 10.1016/j.vetpar.2008.04.007.

HALL, T. A. BioEdit: a user-friendly biological sequence alignment editor and analysis program for Windows 95/98/NT. Nucleic Acids Symposium Series, v.41, p.95-98, 1999.

ISO 16140. Microbiological of food and animal feeding stuffs - Protocol for the validation of alternative methods, 2003. Available from: <http://www.iso.org/iso/home/store/catalogue tc/ catalogue_detail.htm?csnumber $=30158>$. Accessed: Mar. 08, 2016.

ISO 17025. General requeriments for the competence of testing and calibration laboratories, 2010. Available from: $<$ http:// www.iso.org/iso/home/store/catalogue_tc/catalogue_detail. htm?csnumber=39883>. Accessed Mar. 08, 2016.

JULIAN, T. R.; SCHWAB, K. J. Challenges in environmental detection of human viral pathogens. Current Opinion in Virolology, v.2, n.1, p.78-83, 2012. Available from: <http://www.sciencedirect.com/science/article/pii/ S1879625711001611>. Accessed: Mar. 08, 2016. doi: 10.1016/j.coviro.2011.

KINKER, D. R. et al. Evaluation of serological tests for the detection of pseudorabies $\mathrm{gE}$ antibodies during early infection. Veterinary Microbiology, v.55, n.1, p.99-106, 1997. Available from: <http:// www.sciencedirect.com/science/article/pii/S0378113596013089>. Accessed: Mar. 08, 2016. doi: 10.1016/S0378-1135(96)01308-9.

MA, W. et al. Development of real-time polymerase chain reaction assays for rapid detection and differentiation of wild-type pseudorabies and gene-deleted vaccine viruses. Journal of Veterinary Diagnostic Investigation, v.20, n.4, p.440-447, 2008. Available from: $<$ http://vdi. sagepub.com/content/20/4/440.full.pdf + html $>$. Accessed: Mar. 08, 2016. doi: $10.1177 / 104063870802000405$.

MÜLLER, T. et al. Pseudorabies virus in wild swine: a global perspective. Archives of Virology, v.156, n.10, p.1691-1705, 2011. Available from: $<$ http://link.springer.com/article/10.1007\%2Fs00705-011-1080-2>. Accessed: Mar. 08, 2016. doi: 10.1007/s00705-011-1080-2. 
OIE (WORLD ORGANIZATION FOR ANIMAL HEALTH). Chapter 2.1.2. Aujesky Disease. In: Manual of diagnostic tests and vaccines for terrestrial animals. Paris, 2015. Available from: <http://www.oie.int/fileadmin/Home/eng/Health_standards/ tahm/2.01.02_AUJESZKYS_DIS.pdf>. Accessed: Mar. 08, 2016.

PAES, R. C. et al. Serological and molecular investigation of the prevalence of Aujeszky's disease in feral swine (Sus scrofa) in the subregions of the Pantanal wetland, Brazil. Veterinary Microbiology, v.165, n.3-4, p.448-454, 2013. Available from: $<$ http:// www.sciencedirect.com/science/article/pii/S0378113513002009>. Accessed: Mar. 08, 2016. doi: 10.1016/j.vetmic.2013.03.028.

PÉREZ, L. J.; ARCE, H. D. Development of a polymerase chain reaction assay for the detection of pseudorabies virus in clinical samples. Brazilian Journal of Microbiology, v.40, n.3, p.433-438, 2009. Available from: <http://www.scielo.br/pdf/bjm/v40n3/v40n3a02.pdf> Accessed: Mar. 08, 2016. doi: 10.1590/S1517-83822009000300002.
PINHEIRO de OLIVEIRA, T. F. et al. Detection of contaminants in cell cultures, sera and trypsin. Biologicals, v.41, n.6, p.407-414, 2013. Available from: $<$ http://www.sciencedirect.com/science/article/pii/S1045105613001061>. Accessed: Mar. 08, 2016. doi: 10.1016/j.biologicals.2013.08.005.

SAMBROOK, J.; RUSSELL, D. W. Molecular cloning: a laboratory manual. Laurel Hollow, New York. Local: Cold Spring Harbor Laboratory Press, 2001. 2100p.

YOON, H. A. et al. Investigation of pseudorabies virus latency in nervous tissues of seropositive pigs exposed to field strain. Journal of Veterinary Medicine and Science, v.68, n.2, p.143-148, 2006. Available from: $<$ https://www.jstage.jst.go.jp/article/jvms/68/2/68_2_143/ pdf $>$. Accessed: Mar. 08, 2016. doi: 10.1292/jvms.68.143.

YOON, H. A. et al. Molecular survey of latent pseudorabies virus infection in nervous tissues of slaughtered pigs by nested and realtime PCR. Journal of Microbiology, v.43, n.5, p.430-436, 2005. 